\title{
Analisa Asam Salisilat Pada Perlengkapan Persedian Bermerk Bayi Di Pasar Blauran Surabaya
}

\author{
Nastiti Kartikorini ${ }^{1}$ \\ ${ }^{1)}$ Prodi DIII Analis Kesehatan, Fakultas Ilmu Kesehatan, Universitas Muhammadiyah \\ Surabaya \\ Email: nastitikartikorini@gmail.com
}

Tanggal Submit: 23 Agustus 2018

Tanggal Review: 23 Oktober 2018

Tanggal Publish Online:

29 November 2018

\begin{abstract}
Salicylic acid is a substance that is often added to skin care products for acne. In the regulation of the National Agency of Drug and Food Control No. Hk.03.1.23.08.11.07517 in 2011 concerning the technical requirements of cosmetics, salicylic acid levels are limited to $3 \%$ for rinse production and $2 \%$ for other production and are not used for children under 3 years. Using at high doses can cause the baby to bleed, mute and deaf. This is because the structure of the baby's skin is still thin, so it becomes susceptible to irritation and infection. The title of this research is Analysis of Salicylic Acid in the mains supplies barnded baby in the market blauran in Surabaya Region. The purpose identified salicylic acid content with qualitative tests on baby cosmetics circulating in Surabaya. The formulation of this problem is the presence or absence of Salicylic Acid in baby cosmetics. The type of research used descriptive, there were 26 baby cosmetics products in 4 types of products in the form of powder, soap, shampoo, and lotion which were conducted in the Laboratory of Muhammadiyah University of Surabaya in June 2018. Based on the results that found from 26 samples of baby cosmetics in the form of powder as much as $100 \%$ of soap, shampoo and lotions sold in Surabaya were not found for Salicylic Acid. So that all samples met the requirements based on the regulation of the National Agency of Drug and Food Control No.Hk.03.1.23.08.11.07517 in 2011 concerning the technical requirements of cosmetics materials, salicylic acid levels were limited to $3 \%$ not used for children under 3 years.
\end{abstract}

Keywords: Baby supplies, Salicylic Acid

\section{PENDAHULUAN}

Perlengkapan adalah bahan atau sediaan yang dimaksudkan untuk digunakan pada bagian luar tubuh manusia (epidermis, rambut, kuku, bibir dan kulit bagian luar) yang berfungsi mengubah penampilan agar lebih menarik, memperbaiki bau badan, melindungi atau memelihara tubuh pada kondisi baik (Permenkes RI No.1175/MENKES/PER/VIII/2010).

Karena terjadi kontak antara 
perlengkapan dengan kulit, maka ada kemungkinan perlengkapan diserap oleh kulit dan masuk ke bagian yang lebih dalam dari tubuh. Jumlah perlengkapan yang terserap kulit bergantung pada beberapa faktor, yaitu keadaan kulit pemakai, keadaan perlengkapan yang dipakai dan kondisi kulit pemakai. Kontak perlengkapan dengan kulit menimbulkan akibat positif berupa manfaat perlengkapan dan akibat negative berupa efek samping perlengkapan (Wasitaatmadja, 2002).

Untuk melindungi masyarakat dari bahaya penggunaan asam salisilat dengan konsentrasi tinggi dalam sediaan perlengkapan lain juga seperti cream dan gel. Ditemukan ibu-ibu di Surabaya masih menggunakan perlengkapan bayi yang mengandung Asam Salisilat untuk meringankan gatal pada bayinya. Dalam SNI kadar maksimum untuk asam salisilat yang diizinkan terkandung dalam produk kosmetik adalah tidak boleh lebih dari $2 \%$ dan untuk persyaratan lain tidak boleh digunakan pada sediaan untuk anak dibawah usia 3 tahun (Anonim, 2008).

Menurut pendapat salah satu narasumber di apotek Surabaya masih ada dokter yang meresepkan obat yang mengandung asam salisilat. Sedangkan jika obat mengandung asam salisilat tertelan dalam jangka panjang akan menyebabkan batuk, dering di telinga, mual, muntah, diare, pusing, kesulitan bernapas, sakit kepala, mengantuk, disorientasi, gangguan pendengaran, gangguan penglihatan, kongesti paru, kerusakan ginjal, kejang, dan koma.

Asam salisilat (Salicylic acid) dengan nama turunan BHA atau Beta Hydroxy Acid. Biasanya terdapat pada produk perlengkapan untuk mencegah dan mengobati jerawat dan pada obat antiaging. Penggunaan pada dosis tinggi bisa menyebabkan bayi pendarahan, bisu dan tuli. Hal ini disebabkan karena struktur kulit bayi yang masih tipis, sehingga menjadi rentan terhadap iritasi maupun infeksi (Anonim, 2015).

\section{METODE PENELITIAN}

Jenis penelitian ini adalah deskriptif, yaitu bertujuan untuk mengetahui ada tidaknya kandungan asam salisilat pada sediaan perlengkapan bayi .

\section{a. Alat}

Alat yang diperlukan pada pemeriksaan asam salisilat pada perlengkapan bayi yaitu: Beaker glass 50ml, gelas ukur $250 \mathrm{ml}$, kertas saring Whatman no.1, pipet tetes, timbangan, sendok pengaduk, tabung reaksi, beakerglass, corong cawan. 


\section{b. Bahan}

Bahan yang digunakan bedak, sabun, shampoo, dan lotion.

\section{c. Reagensia}

Reagen yang digunakan antara lain:

$\mathrm{FeCl} 3$, Etanol.

\section{d. Prosedur Kerja}

\section{Sampel berbentuk padatan}

Sampel diambil lalu ditimbang sebanyak $100 \mathrm{mg}$, masukkan sampel yang telah ditimbang ke dalam beakerglass dan dilarutkan dalam $5 \mathrm{ml}$ etanol. Menyaring sampel tersebut dengan corong yang sudah dilapisi dengan kertas saring Whatman no. 1, meletakkan kedalam erlenmeyer. Mengambil supernatan 1 $\mathrm{ml}$, meletakkan tabung reaksi kemudian menambahkan sampel tersebut dengan 0,05 $\mathrm{ml} \mathrm{FeCl} 3$. Jika terbentuk warna ungu maka sampel positif mengandung asam salisilat. Membuat control positif asam salisilat yang sama diperlakuan seperti prosedur, berfungsi sebagai pembanding (Farmakope Indonesia edisi III).

Setelah dilakukan pemeriksaan Asam Salisilat pada perlengkapan bayi yang berupa bedak, sabun, shampoo dan lotion yang dijual di Surabaya, maka diperoleh hasil seperti yang tercantum pada tabel dibawah ini :
Tabel 4.1 Hasil Analisa Kandungan Asam Salisilat Pada Perlengkapan Bayi

\begin{tabular}{|l|l|ll|}
\hline No. & Kode & Kandungan & As. \\
& Sampel & Salisilat & \\
& &
\end{tabular}

\begin{tabular}{|l|l|l|l|l|} 
& & $(+)$ & $(-)$ & Ket. \\
\hline 1 & B1 & & $\checkmark$ & MS \\
\hline 2 & B2 & & $\checkmark$ & MS \\
\hline
\end{tabular}

\begin{tabular}{|l|l|l|l|l|}
\hline 3 & B3 & & $\checkmark$ & MS \\
\hline 4 & B4 & & $\checkmark$ & MS \\
\hline 5 & B5 & & $\checkmark$ & MS \\
\hline
\end{tabular}

\begin{tabular}{|l|l|l|l|l|}
\hline 5 & B5 & & $\checkmark$ & MS \\
\hline 6 & B6 & & $\checkmark$ & MS \\
\hline 7 & B7 & & $\checkmark$ & MS \\
\hline
\end{tabular}

\begin{tabular}{|l|l|l|l|l|}
\hline 7 & B7 & & $\checkmark$ & MS \\
\hline 8 & B8 & & $\checkmark$ & MS \\
\hline
\end{tabular}

\begin{tabular}{|l|l|l|l|l|}
\hline 9 & B9 & & $\checkmark$ & MS \\
\hline 10 & B10 & & $\checkmark$ & MS \\
\hline 11 & S1 & & $\checkmark$ & MS \\
\hline
\end{tabular}

\begin{tabular}{|c|c|c|c|}
\hline 11 & S1 & $\checkmark$ & MS \\
\hline 12 & S2 & $\checkmark$ & MS \\
\hline 13 & S3 & $\checkmark$ & MS \\
\hline 14 & S4 & $\checkmark$ & MS \\
\hline 15 & S5 & $\checkmark$ & MS \\
\hline 16 & S6 & $\checkmark$ & $\mathrm{MS}$ \\
\hline 17 & S7 & $\checkmark$ & MS \\
\hline 18 & S8 & $\checkmark$ & MS \\
\hline 19 & S9 & $\checkmark$ & MS \\
\hline 20 & S10 & $\checkmark$ & MS \\
\hline 21 & SH1 & $\checkmark$ & MS \\
\hline 22 & $\mathrm{SH} 2$ & $\checkmark$ & MS \\
\hline 23 & L1 & $\checkmark$ & MS \\
\hline 24 & L2 & $\checkmark$ & MS \\
\hline 25 & L3 & $\checkmark$ & MS \\
\hline 26 & L4 & $\checkmark$ & MS \\
\hline
\end{tabular}

Sumber : Lab. Kimia Kesehatan Prodi D3 Analis UM Surabaya 2018.

$$
\begin{array}{ll}
\text { Ket: } & \\
\text { B } & \text { : Bedak } \\
\text { S } & \text { : Sabun } \\
\text { SH } & \text { : Shampoo }
\end{array}
$$




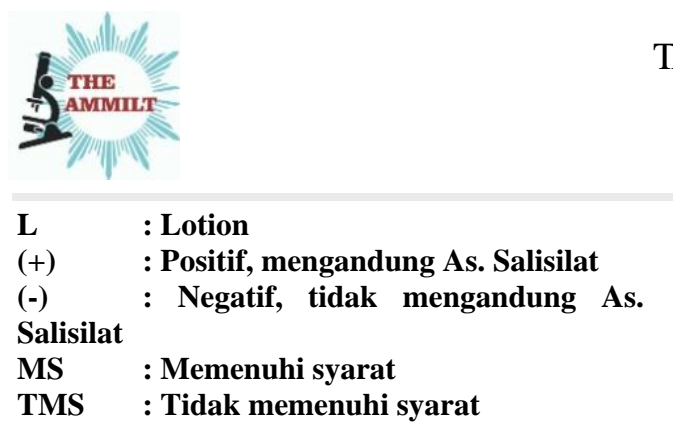

Dari hasil penelitian ditemukan dari 26 sampel perlengkapan bayi yang dijual di Pasar Blauran Surabaya ternyata semuanya (100\%) tidak mengandung Asam Salisilat. Hal ini menunjukkan bahwa kualitas perlengkapan bayi yang beredar di Pasar Blauran itu memiliki kualitas yang baik. Hal ini disebabkan karena sampel yang digunakan bermerk. Berdasarkan peraturan Kepala Badan POM

RI No.Hk.03.1.23.08.11.07517 tahun 2011 tentang persyaratan teknis bahan kosmetika, kadar asam salisilat dibatasi kadarnya kurang dari 3\% tidak digunakan untuk anak dibawah usia 3 tahun.

\section{SIMPULAN DAN SARAN}

\section{Simpulan}

Berdasarkan hasil analisa yang dilakukan pada Asam Salisilat yang terdapat di berbagai macam merek perlengkapan bayi yang dijual di Pasar Blauran di dapatkan hasil dari 26 sampel yang di analisis, $100 \%$ memenuhi syarat Peraturan Kepala Badan tentang persyaratan teknis bahan kosmetika POM RI No.Hk.03.1.23.08.11.07517
The Joumal Of Muhammadiyah Medical Laborationy Technologist

Vol.2No.1 Mei2019

p-ISSN: 2597-3681 e-ISSN:26142805

tahun 2011 dan layak digunakan untuk bayi.

Saran

Perlu dilakukan penelitian lebih lanjut mengenai kandungan asam salisilat pada perlengkapan bayi diluar wilayah Surabaya.

\section{DAFTAR PUSTAK}

Anonim, 2015. Langkah Cerdas Memilih Kosmetik, http://www.pom.go.id/new/ind ex.php/view/berita/8264/Langk ah-Cerdas-MemilihKosmetik.html(Diakses 15 Juni 2017).

Ansel, H.C, 1989. Pengantar Bentuk Sediaan Farmasi Edisi Keempat. Penerbit Jakarta Universitas Indonesia.

Arfina, 2013. Analisis Kandungan Rhodamin B Pada Kosmetik Perona Pipi Yang

Beredar Di Pasar Tradisional Kota Makasar. http://repositori.uinalauddin.ac.id/3018/1/ARFINA .pdf (Diakses 20 Juli 2018).

Astuti, Y.I., Sudirman, I., dan Hidayati, U. (2007): Pengaruh Konsentrasi Adaps Lanae Dalam Dasar Salep Cold Cream Terhadap Pelepasan Asam Salisilat, Pharmacy, Vol. 05,Universitas Muhammadiyah Purwokerto.

Badan POM RI, 2009, Publik Warning/Peringatan tentang Kosmetik Mengandung Bahan Berbahaya/Bahan Dilarang, Jakarta. 
BPOM Republik Indonesia. 2011.

Peraturan Kepala Badan

Pengawasan Obat dan Makanan No.

Hk.03.1.23.08.11.07517 Tahun 2011 tentang Persyaratan Teknis Bahan Kosmetika.

Damayuda,2010.http://damayuda.ki miaorganik.com/2010/12/asamsalisilat-c7h6o2.pdf . (Diakses 31 Juli).

Departemen Kesehatan Republik Indonesia. 1979. Farmakope Indonesia. Edisi III. Jakarta: Departemen Kesehatan RI.

Dep Kes RI, 1988, Pedoman Pengujian Mutu Sediaan Rias, Jakarta.

Dirjen POM, 1985.Formularium Kosmetika Indonesia. Departemen Kesehatan RI.

Djajadisastra, 2005. Tekhnologi Kosmetik. Tangerang : Departemen Farmasi FMIPA Universitas Indonesia. http://ik.pom.go.id/v2016/katal og/Asam\%20Salisilat.pdf.

(Diakses 7 Juli 2018).

Irwandi, Dedi. 2014. Experient's of Organic Chemical. Jakarta : UIN Press.

Jaelani, 2009. Ensiklopedi Kosmetika Nabati Edisi 1. Penerbit Pustaka Populer Obor. Jakarta.
PerMenkes RI, 2010. Menteri Kesehatan Republik Indonesia Nomor 1175/MenKes/PER/VIII/2010 Tentang Izin Produksi Kosmetika, Jakarta.

Putridiniati,2013.http://putridiniati.bl ogspot.com/2013/03/sifatkeasaman-dan-kebasaanturunan.pdf. (Diakses 10 juli).

Soeryati, Sri, 2002. Sediaan kosmetika, departemen pendidikan nasional Unpad, Bandung.

Sulistyaningrum, K.S., Nilasari, H., dan Effendi, H.E. (2012): Penggunaan Asam Salisilat dalam Dermatologi, J Indon Med Assoc, Volum: 62, Nomor: 7.

Tjsianturi, 2013. Penetapan Kadar Asam

Salisilat.http://tjsianturi.blogsp ot.com/2013/11/penetapankadar-asam-salisilatdalam.html.(Diakses 28 juli).

Tranggono, RI. Dan Fatma Latifah, 2007. Buku Pegangan Ilmu Pengetahuan Kosmetik. Penerbit Pustaka Utama, Jakarta.

Wasitaatmadja, S. M, 2002. Penuntun Ilmu Kosmetik Medik. Penerbit Universitas Indonesia. 